\title{
The impact of the Brazilian financial crisis on the food industry
}

Carla Cristiane Sokulski carlacristiane2@hotmail.com Federal University of Technology Paraná (UTFPR), Ponta Grossa, Paraná, Brazil

\section{Gustavo Tadra Waldmann} gustavotadra@gmail.com Federal University of Technology Paraná (UTFPR), Ponta Grossa, Paraná, Brazil

Thales Miquéias dos Santos thales_t.m.s@hotmail.com
Federal University of Technology Paraná (UTFPR), Ponta Grossa, Paraná, Brazil

\section{Moisés Barbosa Junior} moisesjrbarbosa@gmail.com Federal University of Technology Paraná (UTFPR), Ponta Grossa, Paraná, Brazil

\section{Eliane Pinheiro}

elianepinheirouem@gmail.com

Federal University of Technology Paraná (UTFPR), Ponta Grossa, Paraná Brazil

\begin{abstract}
This paper attempts to identify the impact of the 2015 economic crisis on the economic and financial scenario of the Brazilian food industry between 2012-2016. For this, a descriptive study with a quantitative approach was carried out in 15 food industry companies listed on BM\&FBovespa. The analysis was based on the financial economic indicators of liquidity, profitability, indebtedness and economic activity. The data for the study were collected from the database of the BMF\&Bovespa website considering the years from 2012 to 2016, also data tabulation and charting were done in Microsoft Office Excel 2010, using the average of the indicators for each year. Interestingly, the results showed a crisis in the sector and it can be measured its effects on the billing, total assets, net profits of the companies beyond their ability to honor their debts, among others. It was verified that the worst moment of the crisis of the sector was in 2015 and that the Brazilian food industry is already recovering from 2016. Thus, it can be inferred that the economic-financial indicators of the Brazilian food industry presented significant variations in the period of the Brazilian economic crisis of 2015.
\end{abstract}

PALAVRAS-CHAVE: Financial Crisis. Food Industry. Economic-Financial Indicators. 


\section{INTRODUCTION}

Food is present in the lives of all living beings, and as a population grows, its demand for food increases, making the food sector one of the most outstanding in the country, but with the economic crisis that hit the country in 2015 , the scenario became dubious.

In the current Brazilian context, the term crisis is one of the most widely spoken terms in the urban context, from the ordinary citizen belonging to any of the different levels of business to the occupants of high-ranking corporate offices and governmental or non-governmental organizations. In general, for the citizen, the crisis is seen as turbulence, a temporary mismatch or a prolonged confusion in certain segments of daily life (MACHADO, 2008).

The creation of indexes through the analysis of financial statements is a methodology used to analyze economic and financial performance (ALVES; SOUZA, 2017), it is known that the main data to perform an analysis of economic-financial performance and an organization are in the financial statements, and to know the past, present and future situation of the company it is necessary to use as base this set of information, and in this way the economic-financial indicators aim to measure the precise information and predict future situations for the aid in the decision making (RIBEIRO, 2013).

The food sector has been recovering annually. According to ABIA (2017), in 2016 the sector showed a $9.3 \%$ increase in nominal revenue and its real IPCA deflated revenues by $0.6 \%$ in relation to 2015 .In this way, it can be seen that even in a scenario of economic crisis in Brazil since 2015, the food industry has been growing over the years. However, due to the economic crisis of 2015-2016, an in-depth study of the food companies present on the São Paulo Stock Exchange, BM\&FBovespa, in order to understand their economic situation.

Therefore, this article aims to answer the following problems: What is the impact of the economic crisis of 2015 on the economic and financial scenario of the Brazilian food industries between 2012-2016 ? The importance is concentrated in the analysis of the real effects of the crisis of 2015-2016 on the economic-financial performance of organizations based on the economic-financial indicators, contributing to reinforce the concepts that underpin such research.

The present work is structured as follows: after this brief introduction is made the theoretical basis on the concepts that underpin the research, followed by the methodological procedures used to carry it out. After the analysis and discussion of the data is presented, concluding with the final considerations of the work, its limitations and suggestions for future research.

\section{ECONOMIC CRISIS}

The economic crisis is a disruption to the financial markets, typically associated with falling asset prices and insolvency between borrowers and intermediaries, which branches through the financial system, disrupting the market's ability to allocate capital into the economy. In the case of the international economic crisis, disruptions spread across international borders, disrupting the market's ability to allocate capital internationally (HETMANCHUK; SUCHOLINSKI, 2013). 
Economic crises are an important part of the global economic scenario and relevant research has been directed at its economic and political effects. Crises create conditions that substantially affect the labor market, where firms lose capital and go through a difficult phase, especially in the search for additional funds, leading them to reduce labor costs in order to minimize costs. Empirical work in this area has found a robust relationship between crises and the unemployment rate (BLANTON, et al. 2015). This can be seen in the Brazilian scenario, where in 2015, according to IBGE data, the unemployment rate closed at $8.5 \%$, reaching 8.6 million unemployed people, an increase of almost 30\% compared to 2014.

A similar scenario occurred in Greece in 2011, which two years ago had already captured global attention because of its economic crisis caused by its loans from the International Monetary Fund (IMF) and European institutions and had agreed to tough austerity measures. Its economy was expected to contract a further $6.1 \%$ in 2011 and $3 \%$ in 2012 , while the unemployment rate was projected to reach $18.5 \%$ in 2012 , more than double compared to 2008, when it reached 7.7\% (KENTIKELENIS; PAPANICOLAS, 2011).

Argentina, for example, has set up a defense committee to monitor the crisis, in view of exchange rate protection and the regularity of prices of its main commodities, whose elasticities already foreshadow declines in its exports and the increase in its imports, which immediate reflections on the level of domestic prices, the presumed gradual return of inflation (MACHADO, 2008).

There is an increase in the number of studies that investigate how people understand the world economy, motivated not only by the academic interest in the population's perception of economic processes, but also because economic activity (e.g. inflation, unemployment rate, interest rate) is affected by the way people perceive it (LEISER, et al., 2015).

In 1997 and 1998 the economic and financial crisis disrupted Indonesia's manufacturing sector, and the impact of the crisis came in different forms depending on whether the firms were highly indebted or not. Only in 1998 that the crisis had its greatest impact on domestic market industries, the sharp decline in consumer purchasing power caused by inflation (WIE, 2000).

\section{ECONOMIC AND FINANCIAL INDICATORS}

The economic-financial indicators are methodologies that allow a careful and effective analysis of the financial condition of a company or economic sector, and seek to present the past, present and future situation of the organization, according to Matarazzo $(1998$, p.153) "is the relationship between accounts or group of accounts of the Financial Statements, which aims to evidence a certain aspect of the economic or financial situation of a company".

The creation of indicators through the analysis of the financial statements is a practice widely used to obtain an analysis of economic and financial performance of companies, in which the main objective is to assist decision making. The indicators make it possible to extract trends that can be compared to the indexes with preestablished patterns (ALVES; SOUZA, 2017).

Some researchers such as Bortolluzzi et al. (2011), Matarazzo (2010) and Marion (2012) divide the economic-financial indicators into three groups: liquidity indices, 
profitability indices and capital structure indices. On the other hand, Gitman (2002) and Assaf Neto (2014) divide them into four main groups: liquidity indices, activity indices, debt indices and profitability indices. Assaf Neto (2014) and Gitman (2002) describe that the indebtedness index helps managers in their companies' debt analysis, as well as the capacity to fulfill their obligations (SILVA, 2015).

Liquidity ratios assess the company's ability to pay against its financial obligations (ASSAF NETO, 2014). They are used for companies to observe their structure, since to meet short-term financial obligations it is necessary to have available resources to support such obligations (RIBEIRO et al., 2013).

The profitability index represents the economic success achieved by the company in a certain period of time (SILVA, 2015). It represents the company's financial health, business confidence and wealth (GARTNER; GARCIA, 2005).

Indebtedness index is used to estimate the structure of the company's resources, represent how the third-party resources are being invested by the company and its relative shareholding in equity. Through this index one can understand some points used to evaluate the degree of financial commitment and its capacity of the company to fulfill these long-term commitments to its creditors (RIBEIRO et al., 2013).

The activity index represents the operational cycle, which according to Passaia et al. (2011) measure the efficiency with which the financial resources are invested by the company in its Current Assets.

Indicator calculations provide accounting information recognized as the primary source for analyzing an organization's performance. In order to obtain an efficient analysis, it is necessary to select a number of indicators, since when evaluating financial indicators individually and over time, it is also possible to make comparisons with the best companies in the sector, forming parameters to improve the organization's administration system (ALVES; SOUZA, 2017).

\section{FOOD INDUSTRY}

According to a study by the Getúlio Vargas Foundation (2016), the food industry in Brazil accounted for $10 \%$ of GDP in June 2016 , with revenues in excess of $R \$ 480$ billion and responsible for $15 \%$ of all jobs in the industry. The study also states that Brazil is one of the largest players in the world in agribusiness, but the Brazilian food industry does not, despite being diversified and coveted by both exclusivity and quality. In this segment, $54 \%$ of the revenue of the entire sector came from three large groups of companies, the rest being distributed by small and medium-sized companies.

The annual report of the United States Department of Agriculture, Brazil Food Processing Ingredients states that Brazil's agriculture sector is one of its bases, accounting for $30 \%$ of Brazil's GDP in 2014. In addition, Brazil is one of the major world powers in several commodities, being the world's largest producer of sugar, coffee and frozen concentrated orange juice; the world's second largest producer of soybeans, beef and poultry; third in corn and pork and fifth largest producer of cotton. The report adds that the Brazilian processed food industry was responsible in 2014 for $9.5 \%$ of a total of $\$ 2.2$ trillion of GDP (USDA, 2015).

The Brazilian food industry recorded exports of US\$31.5 billion and revenues of US\$ 614.3 billion in 2016. In the sector, there was an investment of R\$ 8.9 billion, with 
$\mathrm{R} \$ 11.6$ billion in mergers and acquisitions and directly generating more than 1.6 million jobs in Brazil, the most used sector in the manufacturing industry (ABIA, 2016).

Real sales in the industry were practically stable until the middle of 2014, when the Brazilian economic crisis began to accentuate. Beginning in May 2014, sales began to decelerate rapidly. The sector started to show a drop in sales from October 2015, reaching the lowest level of $-4.3 \%$ in March 2016, as can be seen in Figure 1. At the same time, Brazil was going through a troubled moment in politics, since a crisis was created that led to the impediment of then-President Dilma Rousseff in 2016 (SENADO NEWS, 2016).

Figure 1: Deceleration of the food industry

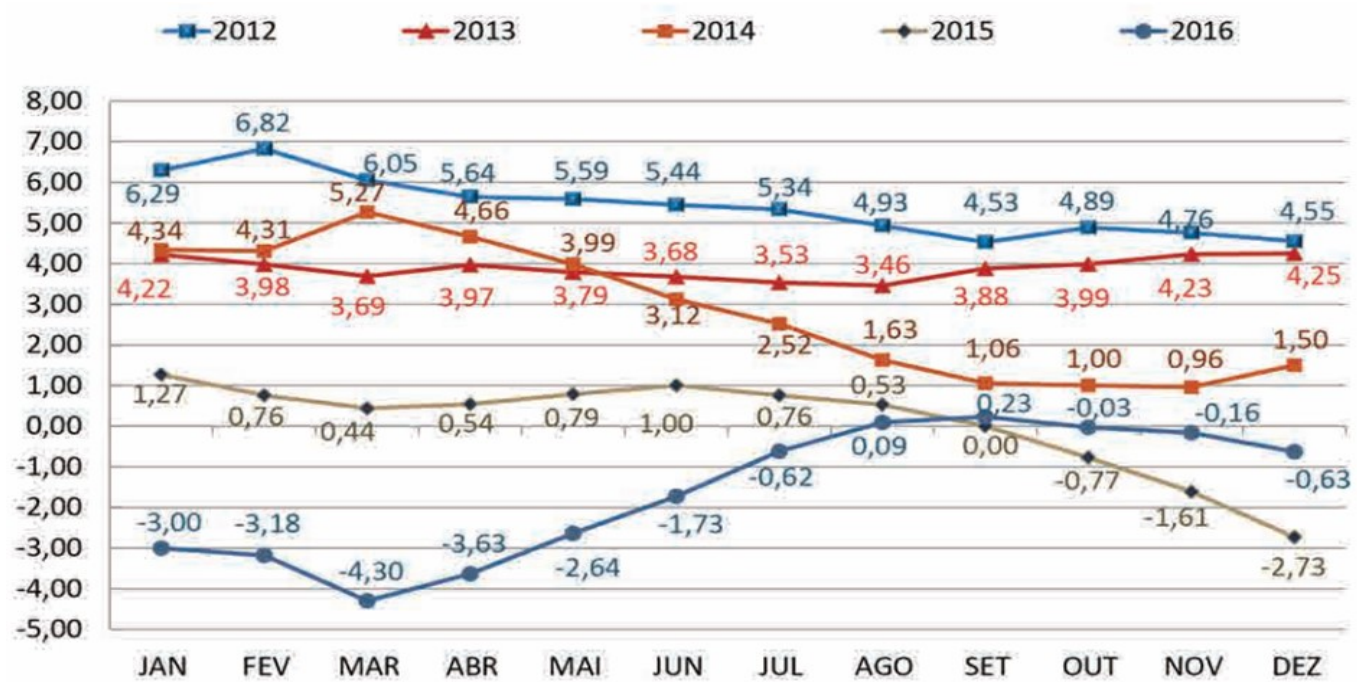

* Real Sales (var \% acum. 12M).

Source: ABIA, (2016)

After the inauguration of the new Brazilian government important measures were taken and structural reforms returned to the agenda (FGV, 2016). Inflation as measured by the IPCA, which had reached the level of $10.67 \%$ in December 2015 , fell to $6.29 \%$ in December 2016. The accumulated inflation until July 2017 was $1.43 \%$, against $4.96 \%$ in the same period of the previous year, $6.83 \%$ in the same period of 2015 and $3.76 \%$ in the same period of 2014. In June 2017 there was deflation, something that had not happened since June 2006, of $-0.23 \%$ (IBGE, 2017). By 2017, the Central Bank of Brazil projects a slight growth in the Brazilian GDP of $0.4 \%$ (BACEN, 2017).

At the same time as the political events mentioned, the food industry started to increase its sales from April 2016 (Figure 1), reaching the end of the year presenting the end of a cycle of falls.

The food industry is one of the most responsible for generating jobs in Brazil. During the crisis there was a considerable increase in the unemployment rate. The installed capacity utilization level of the manufacturing industry averaged $74.6 \%$ in the second quarter of 2017 , up from $78.6 \%$ over the previous five years' average. The unemployment rate that was less than $7 \%$ in January 2015 , practically doubled until mid-March 2017 (BACEN, 2017). According to the ranking of the largest companies in Brazil produced by Valor Econômico (2017), 11 are from the food sector. In addition, five of them stand out for their high revenues. While the 6th largest company in the sector has gross revenues of approximately $\mathrm{R} \$ 19$ billion; Cargill which is in the fifth place recorded in 2016 revenues of $\mathrm{R} \$ 32$ billion. At the top is JBS, the second largest 
Brazilian company, behind only Petrobras with revenues of $R \$ 170.38$ billion. In second place is Ambev with gross revenue of $\mathrm{R} \$ 45.6$ billion, third place is Bunge with revenues of $\mathrm{R} \$ 35.3$ billion and fourth is BRF, whose revenue in 2016 was $\mathrm{R} \$ 32,7$ billion.

\section{METHODOLOGICAL PROCEDURES}

The study aims to identify the impact of the economic crisis of 2015 on the economic and financial scenario of the Brazilian food industry between 2012-2016. As to the objective, the study is classified as descriptive, to the point where it describes the characteristics of a certain group of companies. The approach to the problem is classified as quantitative. The research population covers the food industries listed on BM\&FBovespa. And the time period corresponds to the years 2012 to 2016. The data collection for this research was done through the database of the companies of the national food sector listed on the BM\&FBovespa, from the income statements and balance sheets. In order to characterize the economic and financial performance of the food industry, the indicators of liquidity, activities, indebtedness and profitability were calculated, as shown in Table 1.

Table 1 - Economic and financial indicators applied

\begin{tabular}{|c|c|}
\hline Indicators & Formula \\
\hline \multicolumn{2}{|c|}{ Liquidity Ratios } \\
\hline \multirow{2}{*}{ Current liquidity } & Current assets \\
\hline & Current Liabilities \\
\hline \multirow{2}{*}{ Dry Liquidity } & Current Assets - Inventories \\
\hline & Current Liabilities \\
\hline \multirow{2}{*}{ Immediate liquidity } & Availabilities \\
\hline & Current Liabilities \\
\hline \multirow{2}{*}{ General Liquidity } & Total Assets \\
\hline & Total Liabilities - Shareholders' Equity \\
\hline \multicolumn{2}{|c|}{ Indices of Indebtedness } \\
\hline \multirow{2}{*}{ General Indebtedness } & Current Liabilities + Non-Current Liabilities x 100 \\
\hline & Total Liabilities \\
\hline Impairment of Shareholders' Equity & INOn-Curreml Assets x 100 \\
\hline \multirow{2}{*}{ Non-Current Liabilities / Shareholders' Equity } & Non-Current Liabilities x 100 \\
\hline & Net worth \\
\hline \multirow{2}{*}{ Interest coverage index } & Profit before interest and income tax \\
\hline & Interest \\
\hline \multicolumn{2}{|c|}{ Profitability Indices } \\
\hline \multirow{2}{*}{ Gross Margin } & Gross Profit x 100 \\
\hline & Net operating revenue \\
\hline \multirow{2}{*}{ Operating Margin } & Profit before interest and income tax $x 100$ \\
\hline & Net operating revenue \\
\hline \multirow{2}{*}{ Net margin } & Net Profit x 100 \\
\hline & Net operating revenue \\
\hline \multirow{3}{*}{ ROA } & Net Profit x 100 \\
\hline & Total Assets \\
\hline & Net Profit x 100 \\
\hline ROE & Net worth \\
\hline
\end{tabular}




\begin{tabular}{|c|c|}
\hline \multicolumn{2}{|c|}{ Activity Indices } \\
\hline \multirow{2}{*}{$\begin{array}{l}\text { Average Collection Periods or } \\
\text { Receipts }\end{array}$} & Duplicates receivable $\times 360$ \\
\hline & Gross Revenue \\
\hline \multirow{2}{*}{ Rotation of duplicates receivable } & 360 days \\
\hline & Medium collection period \\
\hline \multirow{2}{*}{ Average Storage Period } & Stocks x 360 \\
\hline & Cost of Goods Sold \\
\hline \multirow{2}{*}{ Inventory Turnover } & 360 days \\
\hline & Average Storage Period \\
\hline \multirow{2}{*}{ Total Asset Turnover } & Sales \\
\hline & Total Assets \\
\hline
\end{tabular}

Source: Adapted from Matarazzo (2010) e Assaf Neto (2014)

Based on the formulas presented in Table 1, the calculations were performed using spreadsheets in Microsoft Office Excel 2010 software, using the simple arithmetic mean of each year analyzed for the group of companies in the sector. And for a better presentation of the results, it was illustrated with the construction of graphs.

\section{ANALYSIS AND DISCUSSION OF DATA}

The accounting data of 18 companies listed on the BM\&FBovespa were collected to analyze the economic and accounting indices of the sector. However, it was decided to keep only 15 of them because the other 3 distorted the data of the sector. The companies excluded from the analysis were JBS, BRF and Minuspar.

JBS and BRF were excluded for similar reasons. Both are much larger than any other company in the industry, causing complete distortions when calculating averages of net operating revenue, assets, liabilities, net income and others. In addition, as one wishes to analyze how the Brazilian crisis of 2015 affected the national companies, there were also distortions because these two companies had a large amount of assets abroad, making them less susceptible to the national crisis than the other companies with part of its assets in Brazilian territory. Minuspar was excluded because it had poor financial results since 2012 that is well before the crisis reached its most critical level. As a result, the company caused distortions in the analysis of the financial indices of the entire sector. Table 2 shows the companies analyzed and their respective sectors.

Table 2 - Companies analyzed and sectorization

\begin{tabular}{|c|c|}
\hline Sector & Companies \\
\hline $\begin{array}{c}\text { Non-cyclical / agricultural consumption / } \\
\text { Agriculture }\end{array}$ & $\begin{array}{c}\text { Brasilagro - Pomifrutas - SLC Agrícola - } \\
\text { Terra Santa Agro }\end{array}$ \\
\hline $\begin{array}{l}\text { Non-Cyclic Consumption / Processed Foods / } \\
\text { Meat and Derivatives }\end{array}$ & Excelsior - Marfrig - Minerva \\
\hline $\begin{array}{l}\text { Non-Cyclic Consumption / Processed Food / } \\
\text { Miscellaneous Food }\end{array}$ & $\begin{array}{c}\text { J. Macedo - Josapar - M. Dias Branco - } \\
\text { Oderich }\end{array}$ \\
\hline $\begin{array}{c}\text { Non-Cyclic Consumption / Beverage / Beers } \\
\text { and Soft Drinks }\end{array}$ & Ambev \\
\hline $\begin{array}{l}\text { Non-Cyclic Consumption / Miscellaneous / } \\
\text { Miscellaneous Products }\end{array}$ & Hypermarcas \\
\hline $\begin{array}{c}\text { Non-Cyclic Consumption / Trade and } \\
\text { Distribution / Food }\end{array}$ & P. Açucar \\
\hline $\begin{array}{c}\text { Cyclic Consumption / Hotels \& Restaurants / } \\
\text { Restaurants \& Similar }\end{array}$ & IMC \\
\hline
\end{tabular}


Source: Own authorship, (2018)

Figure 2 shows the Total Assets, Net Operating Revenue and Net Income of the Brazilian food sector in the period between 2012 and 2016.

Figure 2: Total Assets, Net Operating Revenue and Net Income of the food sector (in millions R\$)

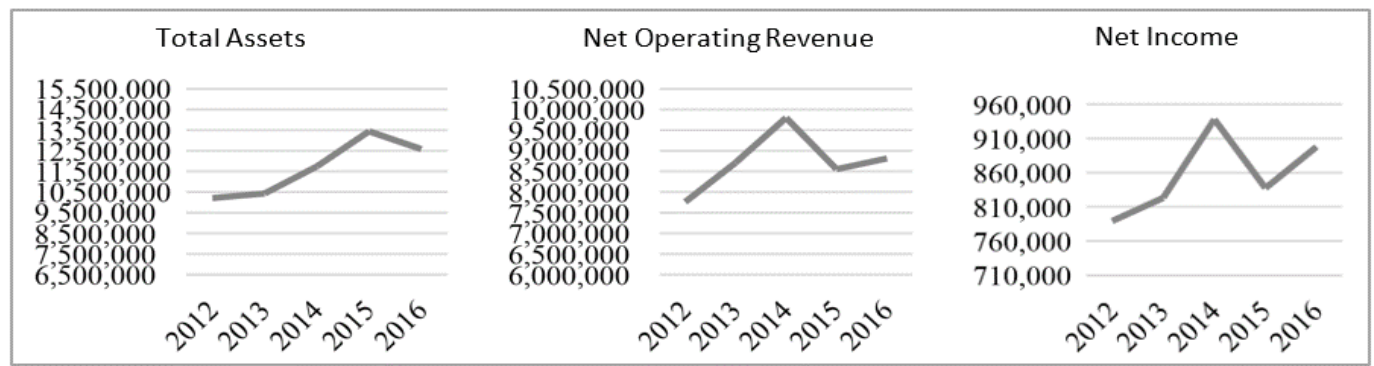

Source: Own authorship, (2018)

Total Assets grew in the period between 2012 and 2015, with a decrease in 2015. The sector's operating revenue has grown consistently from 2012 to 2014, showing a strong contraction of $12.7 \%$ in 2015 and a slight recovery of 3\% in 2016 . The fall in sales shows the most critical year for the sector in the analyzed period, being precisely the most intense period of the crisis according to (ABIA, 2016). Regarding the net profit, the results showed growth of $4.3 \%$ in 2013 and $13.9 \%$ in 2014 . However, when the crisis began in 2015 , the sector recorded a contraction in profits of $10.7 \%$, returning to grow in 2016 when there was an average increase of $7.2 \%$ in the net profit of the sector.

Figure 3: Total assets of the food sector (in millions $\mathrm{R} \$$ )

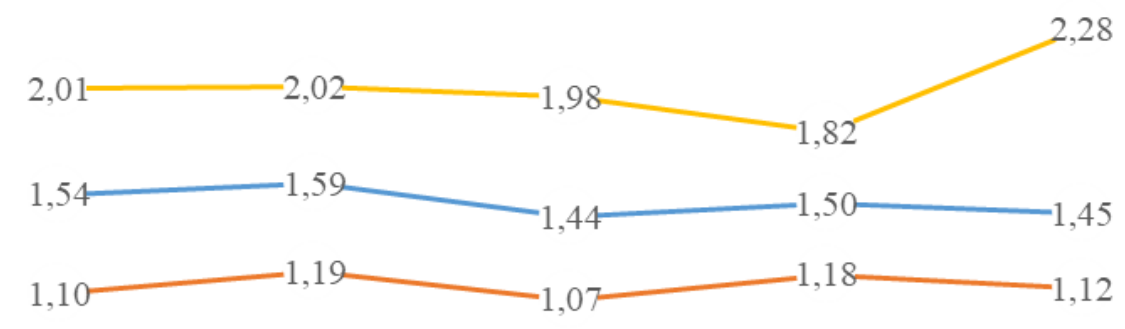

$$
\begin{aligned}
& 0,36-0,38-0,41 \longrightarrow 0,36-0,41 \\
& \begin{array}{llll}
2012 & 2013 & 2014 & 2015
\end{array} \\
& \text { - }- \text { Current liquidity } \\
& \text { - } \quad \text { Immediate liquidity } \\
& \text { - - Dry liquidity } \\
& \text { - } \quad \text { General liquidity }
\end{aligned}
$$

Source: Own authorship, (2018)

Figure 3 presents the liquidity indices of the food sector. Considering that, the liquidity indices are directly linked to the financial situation of the company, in that the higher the value of the indices, the better is the financial situation of the company. The index is considered acceptable for industries when equal to 2 (ASSAF NETO, 2014; GITMAN, 2002). 
It should be highlighted the similar behavior between the current and dry liquidity indices, with a peak in 2013 and a minimum in 2014, even though the economic crisis having reached Brazil in 2015, there was a development of these indices during the period, due to the increase in the total assets of most companies in the sector. Regarding the general liquidity index, it was observed that even though it had a relation with the current and dry liquidity indices, it showed a stable behavior from 2012 to 2014 , and in 2015, the year of the economic crisis, there was a drop in its liquidity index therefore, since it had a value below 2.00 , it could be considered that the companies did not have enough balance to honor their medium and long-term debt during the period. In the year 2016, the index reached its peak, due to the $9.3 \%$ increase in revenues that the sector presented in the period, showing a healthy behavior after the year of the economic crisis.

Regarding debt indicators, general indebtedness, non-current liabilities on shareholders' equity (non-current liabilities/SE), shareholders' equity immobilization (SE) and interest coverage index were used for the analysis, as shown in Figure 4.

Figure 4: Total Assets of the food sector (in millions R\$)

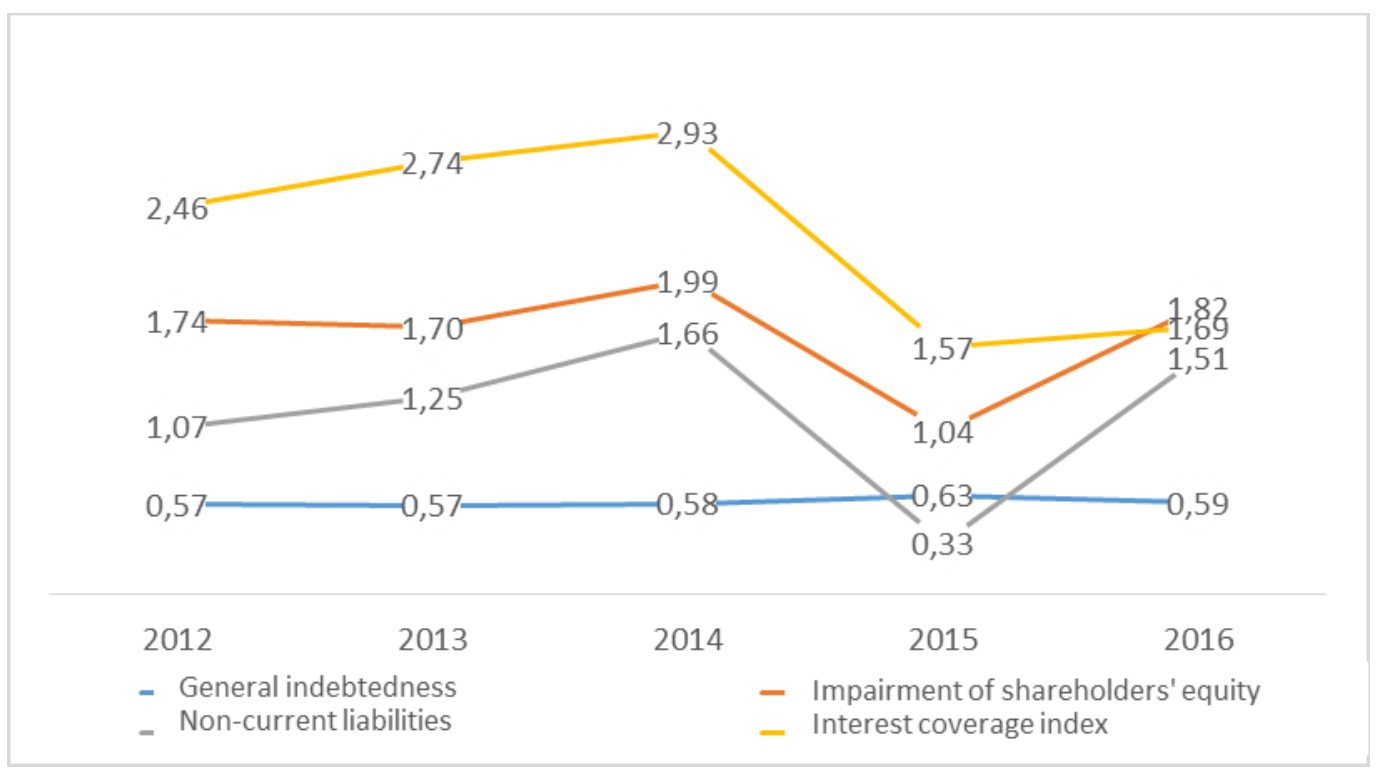

Source: Own authorship, (2018)

Overall indebtedness did not show a marked change over the period, peaking in 2015 , coinciding with the year of the economic crisis, where approximately $63 \%$ of total corporate assets were financed by third-party capital. In non-current liabilities on shareholders 'equity, there was an increase in third-party capital in relation to the shareholders' equity of companies during the year 2012 to 2014, the year that presented its maximum, and in which for each $\mathrm{R} \$ 1.00$ of equity, the companies raised $\mathrm{R} \$ 1.66$ from third party resources, being the minimum point in the year 2015.

Regarding shareholders' equity immobilization, there was a significant drop from 2014 to 2015, indicating that the companies opted to reduce the amount of their property, plant and equipment application during the crisis period. In relation to the interest coverage index, acceptable values were obtained during the year 2014 and in the following years, minimally acceptable indexes, since it is suggested as acceptable values of at least 3.0, and better, as it approximates 5.0 (GITMAN, 2002). Therefore, values far below acceptable values were highlighted, showing that the companies did not have the capacity to honor their contracted interest payments from 2015. 
Figure 5 refers to the Profitability indicators (i.e. gross margin, operating margin, net margin, return on total assets - ROA and return on equity - ROE). Concerning gross margin, it is understood as the measure of the percentage of each monetary unit of sales that remains after the company deducts the value of the goods sold. The operating margin, in turn, measures the percentage of each remaining sales unit subsequent to the deduction of all costs and expenses, except interest, income tax and preferred stock dividends. The net margin is used to measure the percentage of each remaining sales unit after the reduction of all costs and expenses, including interest, taxes and preferred stock dividends. The return on total assets is used to measure the overall effectiveness of management in generating profits from available assets. Finally, the rate of return on equity serves to measure the return on investment of the organization's ordinary shareholders (GITMAN, 2002).

Figure 5: Total Assets of the food sector (in millions R\$)

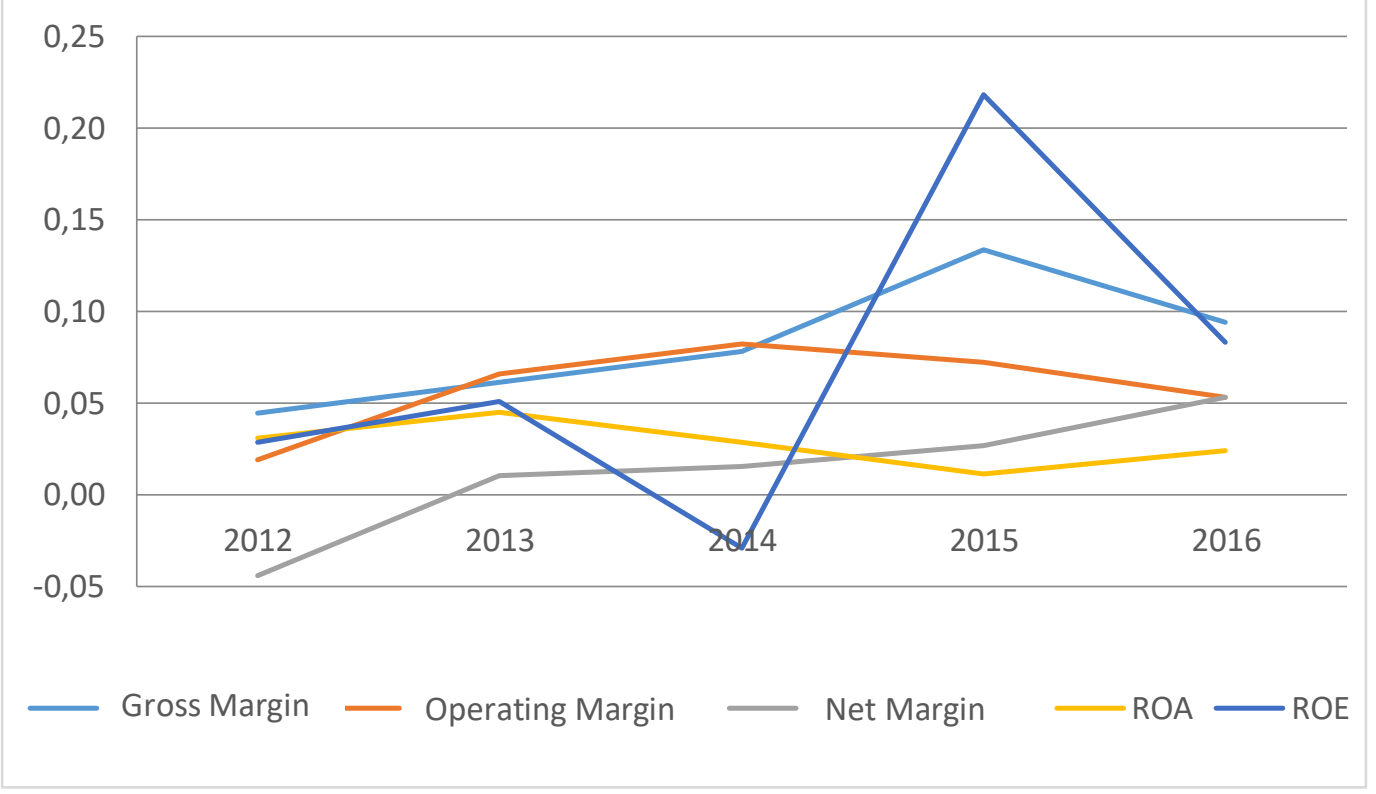

Source: Own authorship, (2018)

The gross margin index reaches its peak in the period of 2015, the year of the economic crisis, showing that food companies have opted to reduce the cost of goods sold. This index is opposed to the operating margin, which increased from 2012 to 2014 followed by a decline in 2015, a worrying scenario, where profit on operations declined and continued to fall the following year. On the other hand, the net margin showed an increase over the whole period studied, even though it is not a considerable value for the size of the companies in the sector.

The return on total assets showed its lowest point in the year 2015, a period in which companies earned on average 1 cent per real invested in assets, compared to the high point of 2013, where they received on average 4 cents per real invested. Lastly, with respect to the return on equity, the maximum point is observed in 2015 , when average companies earned 22 cents per share, as opposed to 2014, which presented the minimum point of the index.

The activity indicators are presented in Figure 6 . The average collection period index is useful for evaluating credit and collection policies, and is significant only in relation to the credit conditions of the companies. The turnover of trade receivables shows how many times a year the collections or receipts from your account balances 
are renewed. The average stocking period reveals how many days, on average, stored products remain in the company, and finally, the inventory turnover indicates how many times a year stock products are renewed (ASSAF NETO, 2014; GITMAN, 2002).

Figure 6: Total Assets of the food sector (in millions R\$)
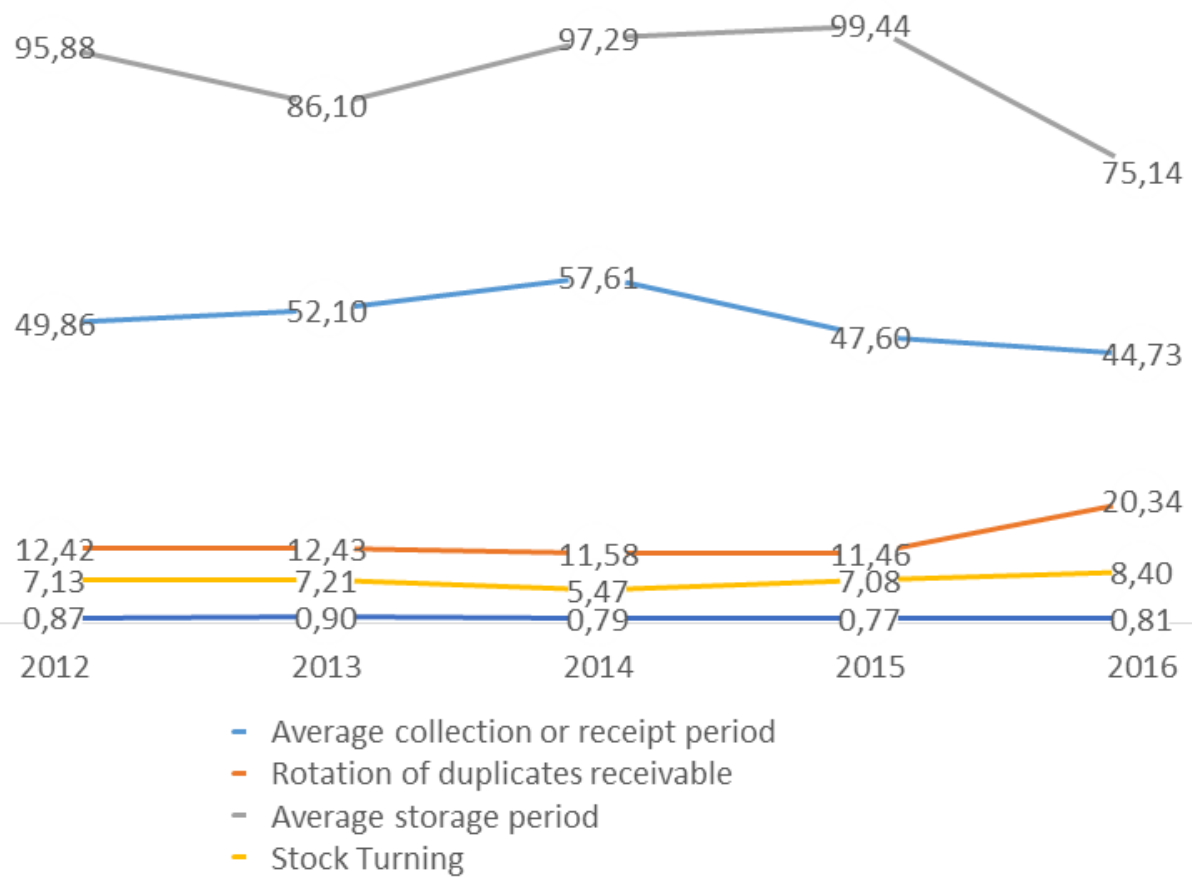

Source: Own authorship, (2018)

The average period of collections/receipts in the period studied remained stable, with only a longer term in 2014 , which shows the maximum point, on the other hand, in relation to the turnover of trade receivables, it was highlighted the maximum point in 2016 , when the renewal of collections or receipts occurred 20.34 times a year, due to the need for capital to recover from the economic crisis of 2015, and in the remaining periods prior to 2016, the index remained stable.

In relation to the average storage period, it is possible to analyze that in the year of 2013, where it presented its minimum point, the companies, on average, kept their inventories for a shorter period, and counterpart in the year 2015, demonstrated their maximum , in which companies kept inventories for a longer period, so, the turnover of stock in the period from 2013 to 2014, there was a decrease, representing their minimum point, and already in 2015 there was an increase in inventory turnover, average for the years prior to 2014.

Finally, the total assets turnover declined in the 2014 period and continued to decline in 2015, demonstrating that the efficiency in the use of its assets declined in those periods and achieved a recovery in 2016. 
The study sought to analyze the impact of the Brazilian financial crisis in 2015 in the Brazilian food industry. For this, 15 companies were selected on the BM\&FBovespa. It was found that the crisis really impacted this industrial sector. Both operating income and net income fell sharply in 2015. As a result, in 2016, companies experienced a reduction in their total assets.

As shown by the sector's liquidity ratios, by 2015 companies have significantly reduced their ability to honor medium-term debt due to a capital reduction for this purpose. Indebtedness indicators showed that the share of third-party capital invested in companies was growing until 2014, showing a sharp decline in 2015 . The general debt reached its peak in the year and 2015. The companies showed a large fall in the rate of interest coverage, which went from a value close to acceptable, for half of that. The indicators of profitability showed that despite the crisis, the sector managed to increase gross margin, net and ROE, as well as, decrease in operating margin and ROA.

In general, the profitability of the sector increased, as opposed to net profit, which fell by $10.7 \%$ in 2015 . Activity indicators showed that companies intensified their debtors' collections from 2015 and that after 2014, the sector increased the turnover of its stocks. Moreover, the products were stored longer in the years 2014 and 2015, presenting the lowest value of the period analyzed in 2016. The average collection period also fell in 2015 and again in 2016, possibly due to the companies' need to earn revenue during the crisis period.

The present work was not intended to make an individual analysis of the companies of the sector, and the sector itself was the object of interest. As a limitation it is possible to mention the elimination of the three companies already mentioned. However, they would cause distortion in the data, generating the possibility for future studies to do the individual analysis of the Brazilian food industries. The data obtained and that evidenced the negative impact in the companies of the food sector of Brazil were taken by the average of all the companies in each year, from 2012 to 2016. This allows the opportunity for future lines of work to do a similar analysis in other sectors or in all the companies listed on BM\&FBovespa, as well as to make a study of all the companies with an individualized approach in order to identify clusters. 


\title{
O impacto da crise financeira brasileira nas indústrias de alimentos
}

\begin{abstract}
RESUMO
O estudo tem como objetivo identificar qual é o impacto da crise econômica de 2015 no cenário econômico-financeiro das indústrias alimentícias brasileiras entre 2012-2016. Para isto, realizou um estudo descritivo com abordagem quantitativa em 15 indústrias do setor alimentício listadas na BM\&FBovespa. As análises deram-se por meio dos indicadores econômicos financeiros de liquidez, rentabilidade, endividamento e atividade. Os dados para o estudo foram coletados do banco de dados do site da BMF\&Bovespa no período de 2012 a 2016, sendo que a tabulação dos dados e elaboração de gráficos e tabelas foi realizada no Microsoft Office Excel 2010, por meio da média dos indicadores para cada ano. Com isso, os resultados demonstraram uma crise do setor e pode-se mensurar seus efeitos no faturamento, ativo total, lucro líquido das companhias além da capacidade destas em honrar seus débitos, entre outros. Verificou-se que o pior momento da crise do setor foi em 2015 e que a indústria de alimentos brasileira já está em recuperação desde 2016. Assim, infere-se que os indicadores econômico-financeiros das indústrias do setor alimentício brasileiro apresentaram variações relevantes no período da crise econômica brasileira de 2015.
\end{abstract}

PALAVRAS CHAVE: Crise Financeira. Indústria de Alimentos. Indicadores EconômicoFinanceiros. 
ALVES E SOUZA, J. Aplicação da Análise Fatorial para identificação dos principais indicadores de desempenho econômico-financeiro em instituições financeiras bancárias. Florianópolis: Revista Catarinense da Ciência Contábil, 2017.

ASSOCIAÇÃO BRASILEIRA DAS INDÚSTRIAS DE ALIMENTAÇÃO (ABIA). Relatório Annual 2016. Retrieved from:

<http://www.abia.org.br/vsn/temp/z2017417RELATORIOANUAL2016.pdf>. Access in: 31 aug. 2018.

ASSAF NETO, A. Finanças corporativas e valor. 7 Ed. São Paulo: Atlas, 2014.

BANCO CENTRAL DO BRASIL (BACEN). Relatório de Inflação Junho de 2017. Retrieved from: <https://www.bcb.gov.br/htms/relinf/port/2017/06/ri201706P.pdf>. Acess in: 29 aug. 2018.

BLANTON, R. G., BLANTON, S. L., PEKSEN, D. Financial Crises and Labor: Does Tight Money Loosen Labor Rights? World Development, v. 76, p. 1-12, 2015. crossref

BORTOLUZZI, S. C. et al. Avaliação de desempenho econômico-financeiro: uma proposta de integração de indicadores contábeis tradicionais por meio da metodologia Multicritério de Apoio à Decisão Construtivista (MCDA-C). Revista Alcance, v. 18, n. 2, p. 200-218, 2011.

FUNDAÇÃO GETÚLIO VARGAS - FGV. A Indústria de Alimentos no Brasil e na América do Sul. FGV Projetos, n. 27, 2016.

GAERTNER, I. R.; GARCIA, F.G. Criação de valor e estratégias de operações: um estudo do setor químico e petroquímico brasileiro. Gestão de Produção, v. 12, n. 3, p. 459-468, 2005. crossref

GITMAN, L. J. Princípios de administração financeira. 7 Ed. São Paulo: Harba, 2002.

HETMANCHUK, A.; SUCHOLINSKI, A. Global Financial Crisis as a symptom of the Market economy turbulences in the 21st century, Економічний вісник, 2013.

IBGE - Instituto Brasileiro de Geografia e Estatística. Em novembro, desocupação foi de 7,5\%. Retrieved from: <http://agenciadenoticias.ibge.gov.br/agencia-noticias/2013agencia-de-noticias/releases/9599-em-novembro-desocupacao-foi-de-7-5.html>. Acess in: 01 sep. 2018. 
IBGE - Instituto Brasileiro de Geografia e Estatística. Série Histórica do IPCA. Retrieved from:

<http://www.ibge.gov.br/home/estatistica/indicadores/precos/inpc_ipca/defaultseries Hist.shtm>. Acess in: 01 sep. 2018.

KENTIKELENIS, A.; PAPANICOLAS, I. Economic crisis, austerity and the Greek public helth system. European Journal of Public Health, v. 22, n. 1, p. 4-5, 2011. crossref

LEISER, D., BENITA, R., BOURGEOIS-GIRONDE, S. Differing Conceptions of the Causes of the Economic Crisis: Effects of Culture, Economic Training, and Personal Impact. Journal of Economic Psychology, Forthcoming, 2015. crossref

MACHADO, J. R. A crise financeira mundial e a América Latina: pragmatismos sem teses inovadoras. Revista Mundorama, 2008.

MARION, J. C. Análise das demonstrações contábeis: contabilidade empresarial. 7 Ed. São Paulo: Atlas, 2012.

MATARAZZO, D. C. Análise Financeira de balanços. 5 ed. São Paulo: Atlas, 1998.

MATARAZZO, D. C. Análise financeira de balanços: abordagem básica e gerencial. 7 Ed. São Paulo: Atlas, 2010.

PASSAIA, C., DASILVA, B. A., \& DEMOZZI, M. Análise Econômica Financeira com utilização de índices. Revista Online de Ciências Sociais Aplicadas em Debates, v. 1, n. 1, p. 26-45, 2011.

RIBEIRO, L. et al. Análise multivariada dos indicadores econômico-financeiros das empresas de construção e engenharia listadas na BM\&FBovespa: um estudo da aplicabilidade da pecking order theory. Gestão e Tecnologia para a Competitividade, 2013.

SENADO NOTÍCIAS. Senado Aprova Impedimento de Dilma Rousseff. Retrieved from: $<$ http://www12.senado.leg.br/noticias/audios/2016/08/senado-aprova-impedimentode-dilma-rousseff>. Acess in: 30 aug. 2018.

SILVA, P. Z. P. Análise da crise de 2012 no desempenho econômico-financeiro das indústrias de energia elétrica listadas na BM\&FBovespa. Porto Alegre: ConTexto, 2015.

USDA FOREIGN AGRICULTURAL SERVICE. Brazil Food Processing Ingredients -Annual Report. GAIN Report Number: BR15013. Retrieved from: 
<http://usdabrazil.org.br/upload/files/Food\%20Processing\%2OIngredients_Sao\%20Paul \%\%20ATO_Brazil_12-7-2015.pdf>. Acess in 30 aug. 2018.

VALOR ECONÔMICO. As 1000 Maiores Empresas, ranking 2017, setor de Alimentos e Bebidas. Retrieved from:

<http://www.valor.com.br/valor1000/2017/ranking1000maiores/Alimentos_e_Bebidas >. Acess in: 01 sep. 2018.

WIE, K. The Impact of the Economic Crisis on Indonesia's Manufacturing Sector. The Developing Economies, p. 420-53, 2000. crossref

SOKULSKI, C.C.. et al. The impact of the Brazilian financial crisis on the food industry. R. Gest. Industr., Ponta Grossa, v. 15, n. 3, p. 43-58, Jul../Set. 2019. Disponivel em: <https://periodicos.utfpr.edu.br/revistagi> Acesso em:

Correspondência:

Carla Cristiane Sokulski

Federal University of Technology - Paraná (UTFPR), Ponta Grossa, Paraná, Brazil.

Direito autoral: Este artigo está licenciado sob os termos da Licença Creative Commons-Atribuição 4.0 Internacional.

\section{(c) (1)}

